\title{
Could Proteomic Research Deliver the Next Generation of Treatments for Pneumococcal Meningitis?
}

\author{
U. R. Goonetilleke, ${ }^{1,2}$ S. A. Ward, ${ }^{1}$ and S. B. Gordon ${ }^{2}$ \\ ${ }^{1}$ Molecular and Biochemical Parasitology, Liverpool School of Tropical Medicine, Pembroke Place, \\ Liverpool L3 5QA, UK \\ ${ }^{2}$ Pulmonary Immunology, Liverpool School of Tropical Medicine, Pembroke Place, Liverpool L3 5QA, UK
}

Correspondence should be addressed to U. R. Goonetilleke, upali.goonetilleke@liv.ac.uk

Received 5 January 2009; Accepted 9 March 2009

Recommended by Joshua Metlay

Streptococcus pneumoniae is the most common bacterial cause of community-acquired meningitis worldwide. Despite optimal antibiotic therapy and supportive care, the mortality of this condition remains very high at 20-30\% in the developed world and over $60 \%$ in under-resourced hospitals. In developed countries, approximately half of the survivors suffer intellectual impairment, hearing loss, or other neurological damage. There is an urgent need for more information about the mechanisms of brain damage and death in pneumococcal meningitis so that new treatments can be designed. Using proteomic techniques and bioinformatics, the protein content of cerebrospinal fluid can be examined in great detail. Animal models have added greatly to our knowledge of possible mechanisms and shown that hippocampal apoptosis and cortical necrosis are distinct mechanisms of neuronal death. The contribution of these pathways to human disease is unknown. Using proteomic techniques, neuronal death pathways could be described in CSF samples. This information could lead to the design of novel therapies to minimize brain damage and lower mortality. This minireview will summarize the known pathogenesis of meningitis, and current gaps in knowledge, that could be filled by proteomic analysis.

Copyright (C) 2009 U. R. Goonetilleke et al. This is an open access article distributed under the Creative Commons Attribution License, which permits unrestricted use, distribution, and reproduction in any medium, provided the original work is properly cited.

\section{Clinical Problem of Meningitis}

Infection of the membranes surrounding the central nervous system (meninges) results in meningitis. Streptococcus pneumoniae, an ovoid gram-positive bacterium [1], is the most common cause of bacterial meningitis [2]. Pneumococci are able to colonise the nasopharynx without developing any serious consequences. Pneumococcal carriage rates in young children vary from over $40 \%$ in developed nations such as USA to $87 \%$ in developing nations such as Gambia $[3,4]$. Pneumococcal carriage rates in adults vary from approximately $10 \%$ in developed nations such as USA to $51 \%$ in developing nations such as Gambia [5]. When pneumococci spread to the sinuses, ear, lung, and blood stream, diseases such as sinusitis, otitis media, pneumonia, and septicaemia can result (Figure 1). As an example pneumococcal meningitis in Malawi has a high fatality rate of $65 \%$ [6] and survivors may develop long-term neurological sequelae, including hearing loss and other focal neurological deficits [7].

\section{Pathogenesis of Meningitis}

Invasion of the central nervous system (CNS) by colonising pneumococci follows an alteration in the balance between the virulence of the bacteria and the defences of the patient. Factors such as common colds or other upper respiratory virus infections alter the lining of the respiratory tract and allow bacteria to enter the bloodstream. Pneumococci then actively translocate across intact endothelial layers [8] by means of specific receptor binding and translocation. Endothelial cells normally separate the blood from neuronal tissue forming a protective blood-brain barrier (BBB). The integrity of the $\mathrm{BBB}$ is compromised by apoptosis of endothelial cells. The BBB breakdown allows further invasion of cerebrospinal fluid (CSF) [9-11]. It has been observed in some children that bacteria can translocate directly from the nasopharynx into the CNS via olfactory neurones [12]. A nonhaematogenous route has also been demonstrated in animal models [13]. 


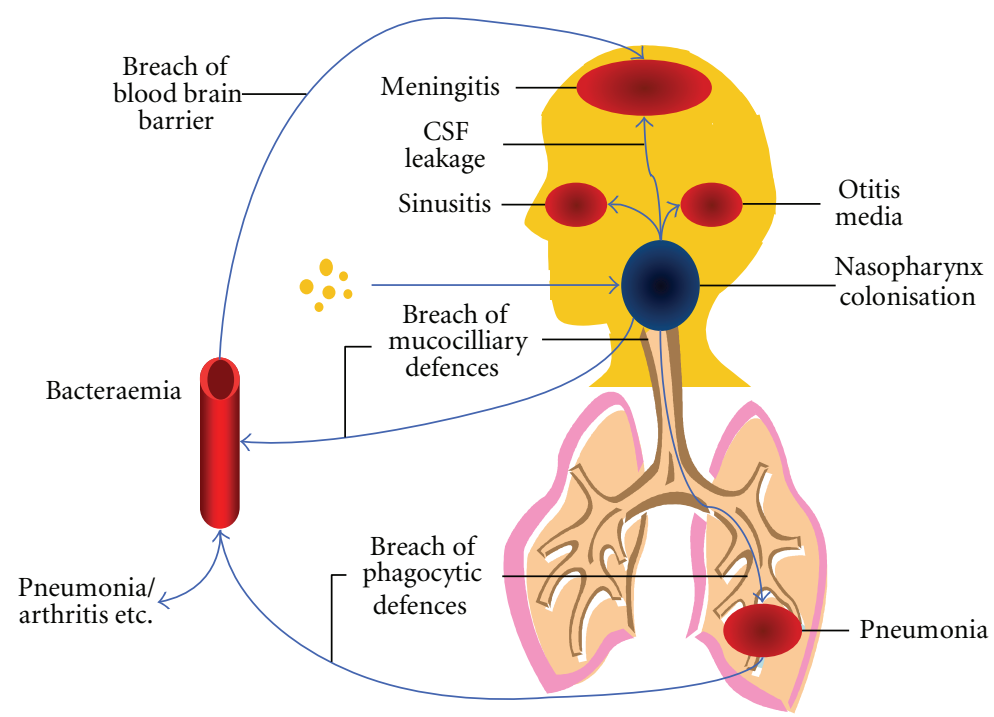

Figure 1: When pneumococci spread to the sinuses, ear, lung, and blood stream, diseases such as sinusitis, otitis media, pneumonia, and septicaemia can result. Invasion of the central nervous system (CNS) by colonising pneumococci follows an alteration in the balance between the virulence of the bacteria and the defences of the patient. Factors such as common colds or other upper respiratory virus infections alter the lining of the respiratory tract and allow bacteria to enter the bloodstream. Pneumococci then actively translocate across intact endothelial layers by means of specific receptor binding and translocation. Endothelial cells normally separate the blood from neuronal tissue forming a protective blood-brain barrier (BBB). The integrity of the BBB is compromised by apoptosis of endothelial cells. The BBB breakdown allows further invasion of cerebrospinal fluid (CSF).

The host inflammatory response to the pneumococcus is initiated by pneumococcal toxins such as pneumolysin and hydrogen peroxide $[14,15]$. Most of the tissue damage associated with meningitis is caused by host responses including the action of phagocytes, secreted granular toxins, cytokines and leukotrienes, matrix metalloproteinases, and the direct pressure effect of cerebral oedema causing ischaemia [16]. In addition pneumococcal proteins have been shown to contribute to neuronal cell death in animal models [17]. Neuronal cell death has been determined to occur via three distinct pathways [18] which are illustrated in Figure 3.

(i) Classic caspase-3-dependent cell death which leads to apoptosis or programmed cell death.

(ii) Caspase-3-independent cell death which leads to pyknosis (irreversible condensation of chromatin in the nucleus of a cell undergoing programmed cell death or apoptosis).

(iii) Necrosis, the unnatural death of cells and living tissue through cell swelling, chromatin digestion, and disruption of the plasma membrane and organelles.

\section{Neuronal Cell Death in the Hippocampus}

Animal models have been used to determine the mechanism of pneumococcal related neuronal apoptosis. In the rabbit model of pneumococcal meningitis, hippocampal apoptosis was found to be the predominant form of neuronal damage $[19,20]$. Inhibition of phosphorylcholine synthesis in mitochondria of neurons in the hippocampal dentate gyrus leads to mitochondrial release of apoptosis inducing factor
(AIF) which in turn causes pyknosis of the hippocampus. In an adult mouse model both caspase-dependent and independent forms of neuronal cell death have been described in the dentate gyrus of adult mice [21]. Bacterial cell wall products initiate mitochondrial release of cytochrome c leading to classic toll-like receptor (TLR) dependentcaspase-3 mediated apoptosis occurring more widely in the brain. Infant rat models of pneumococcal meningitis showed similar neuronal damage patterns to human disease [22, 23]. In the infant rat meningitis model, apoptosis and pyknosis of neurons have been identified in the dentate gyrus of the hippocampus (Figure 2). In humans apoptosis has been identified in the dentate gyrus [24]. Apoptosis primarily affects the subgranular zone containing recently divided immature neurons. Pyknosis occurs throughout the dentate granular cell layer. Both mature and immature neurons are affected as a result [20].

\section{Neuronal Cell Death in the Cortex by Necrosis}

A feature of severe pneumococcal meningitis is ischaemic damage of neurons in the ischaemic core of the cortex which results in necrosis in addition to caspase- 3 dependent cell death in the ischemic core and penumbra $[22,25,26]$. Inflammation of the meninges leads to oxygen and glucose deprivation of neuronal cells. The release of excitatory neurotransmitters from glutamatergic neurons leads to glutamate receptor overactivation, $\mathrm{Ca}^{2+}$ influx and subsequent injury, and eventually neuronal necrosis [27]. Neuronal necrosis and neuronal apoptosis may share a final common path [28], that is, the mitochondrial pathway as illustrated in Figure 3. 


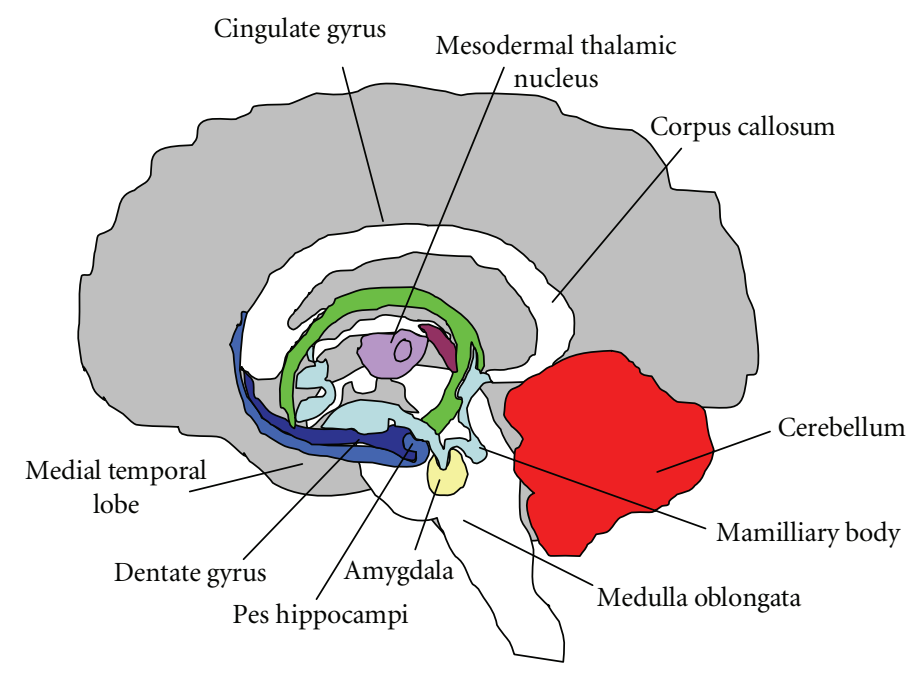

Figure 2: The hippocampus is a part of the forebrain, located in the medial temporal lobe. The hippocampus is used in storing and processing spatial information. In the rabbit model of pneumococcal meningitis, hippocampal apoptosis was found to be the predominant form of neuronal damage. In humans, apoptosis and pyknosis have been identified in the dentate gyrus of the hippocampus. Apoptosis primarily affects the subgranular zone containing recently divided immature neurons. Pyknosis occurs throughout the dentate granular cell layer.

\section{Steroid Therapy}

Most of the information that is known about inflammation has come from animal models, in which neuronal injury may be reduced by modulation of the inflammatory response with steroid adjuvant therapy [29]. In developed nations, steroid adjuvant therapy has been shown to reduce deaths in some adults, particularly in patients with mild pneumococcal meningitis [30]. On the other hand, a large paediatric trial in Malawi demonstrated no benefit from steroids in children with bacterial meningitis [31]. Further, a double blind, randomised, placebo controlled trial of dexamethasone adjuvant therapy in adults with bacterial meningitis in Malawi also showed no advantage at 40 days [32]. The difference seen between Europe and Malawi is likely to have resulted from differences in the severity of the cases. There remains an urgent need for novel adjuvant therapy in the treatment on pneumococcal meningitis worldwide.

\section{Potential for New Therapy}

Critical pathways for new therapy should clearly target the apoptotic and necrotic pathways. For example, citicholine is an intermediate in the synthesis of phosphorylcholine in mitochondrial and cell membranes. It has been shown to prevent neuronal damage when given before and after bacterial infection in animal models of meningitis, regardless of the route of infection $[15,33]$. Alternatively matrix metalloproteinase inhibitors could prevent blood brain barrier damage. Matrix metalloproteinase (MMPs) are a family of zinc-dependent endopeptidases that show affinity to different components of the extracellular matrix. They have been shown to play a role in the breakdown of the bloodbrain barrier and the facilitation of neuroinflammation in bacterial meningitis [34]. In bacterial meningitis, MMPs may contribute to the development of brain injury by both their proteolytic activity on the extracellular matrix and their ability to increase the levels of soluble TNF- $\alpha$, a pivotal element in the meningeal inflammatory process. TNF- $\alpha$ is a strong stimulus for the release and activation of MMPs in the brain $[35,36]$.

\section{Critical Gaps in Knowledge}

There are critical gaps in knowledge that need to be addressed before new therapies can be implemented in meningitis. In particular there is insufficient data to link human death in meningitis with the mechanisms observed in animal models. High levels of CSF apoptosis proteins in patients with neurological damage or death would provide a basis for trials of citicholine. Alternatively, high levels of MMP and MMP-related damage would provide a case for the use of MMP inhibitors. Proteomics' methods provide a modern means of obtaining these pivotal data. Proteomics is the qualitative and quantitative analysis of all expressed proteins present in cells, tissues, or organisms at certain time and under different conditions [37].

The application of proteomics to CSF samples and serum will allow the presence or absence of both high and low abundant proteins to be associated with neurological damage and death in meningitis. Proteomics' approaches allow the analysis of a large spectrum of host and pathogen proteins but cannot yet be applied to the bacterial cell wall components such as lipoteichioic acid (LTA) of pneumococcus. These methods have already been applied in malaria and tuberculosis but have not yet advanced to the treatment of pneumococcal meningitis $[38,39]$.

\section{Proteomic Methods That Can Be Applied to CSF Analysis}

A basic proteomic approach to meningitis will involve the comparison of protein expression in normal and disease 


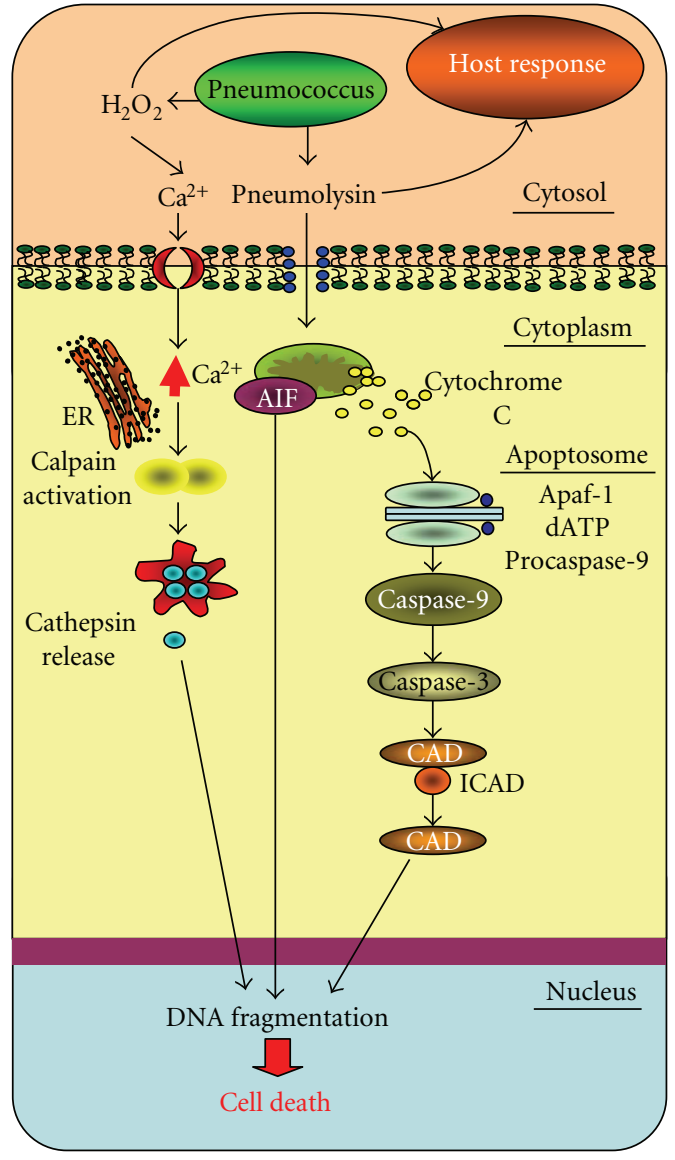

(a)

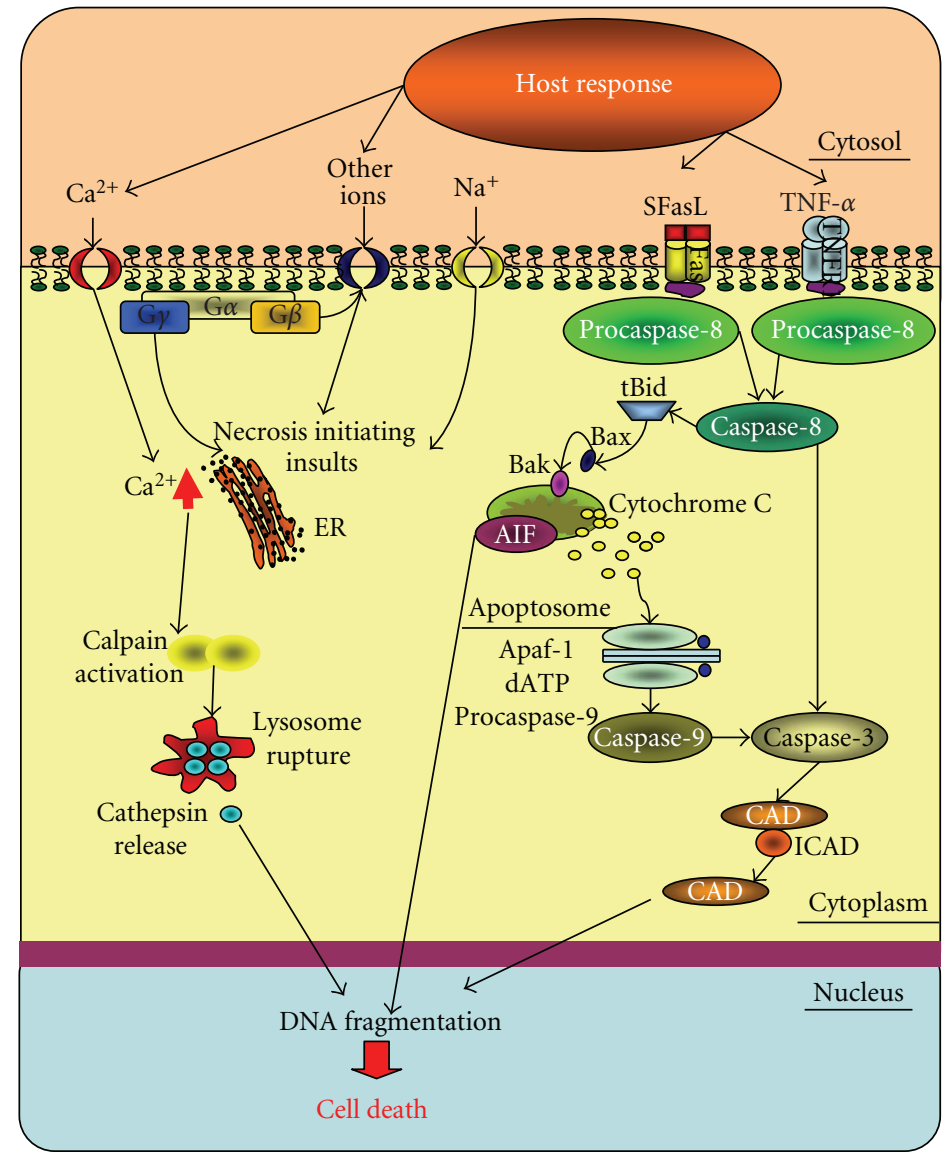

(b)

Figure 3: (a) The cell wall of S. pneumoniae has a diverse protein population. Proteins such as pneumolysin can trigger apoptosis on entering cells by destruction of the mitochondria. In addition oxidising components such as hydrogen peroxide can trigger apoptosis and necrosis. (b) The host immune response will most likely be made up of complement and cytokines which can activate transmembrane death receptors such as Fas. This will cause receptors to aggregate together on the cell surface leading to apoptosis. The adaptor protein Fas-associated death domain protein (FADD) activates caspase-8, an initiator protein, to form a signal complex to directly activate caspase-3. Active caspase- 8 can also cleave BID protein to tBID, which acts as a signal on the membrane of mitochondria to facilitate the release of cytochrome $c$ in the intrinsic pathway. The mitochondrial stress pathway is initiated when proapoptotic proteins in the cytoplasm, BAX, and BID stimulate the rupture of the mitochondria. The release of mitochondrial content is aided by the protein BAK. In the caspase dependant pathway, cytochrome $\mathrm{c}$ released from the mitochondria forms a complex in the cytoplasm with adenosine triphosphate (ATP) and apoptotic protease activating factor-1 (Apaf-1). This complex activates caspase-9, an initiator protein. In return, the activated caspase- 9 works together with the complex of cytochrome c, ATP, and Apaf-1 to form an apoptosome, which in turn activates caspase-3, the effector protein that initiates degradation. The caspase independent pathway (pyknosis) is as a result of apoptosis inducing factor (AIF). The necrotic pathway is activated in severe meningitis. Alterations in the concentration of cytoplasmic calcium could signal the mobilisation of executioner cathepsin proteases and other hydrolases, through calpain activation. Calpains have been implicated in the activation of proapoptotic caspase proteases; hence the later steps of necrosis correlate with the later steps of apoptosis.

CSF to identify aberrantly expressed proteins [37]. Proteomic techniques applicable to CSF are either top-down, that is, a "shotgun" approach to protein identification or bottom-up, that is, the identification of proteins from the peptide spectra of a digested protein $[40,41]$ as shown in Figure 4.

\section{Top-Down Proteomics}

2-Dimensional Polyacrylamide Gel Electrophoresis (2D PAGE) with protein identification using mass spectrometry [42] involves the separation of proteins according to isoelectric point and molecular weight. The proteins are excised out of the gels and either directly interrogated by mass spectrometry (true top down proteomics) or are digested with specific enzymes prior to analysis using mass spectrometry. The isoelectric point of a protein and their mass aids identification of proteins and posttranslational modified proteins can be identified through the position in the gel at a comparatively low cost. However 2D PAGE is slow, and high-abundant proteins in the gel can confound small proteins.

Protein microarrays consist of different protein binding molecules, for example, antibodies spotted at separate identifiable locations on a chip made from glass or silicone to 


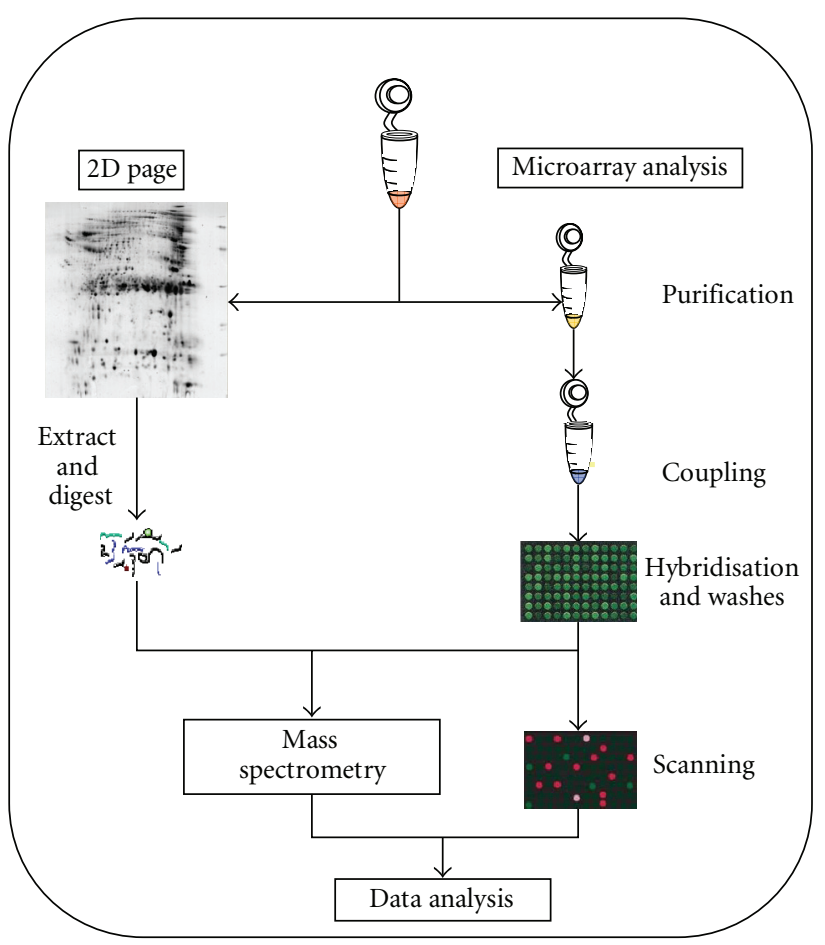

(a)

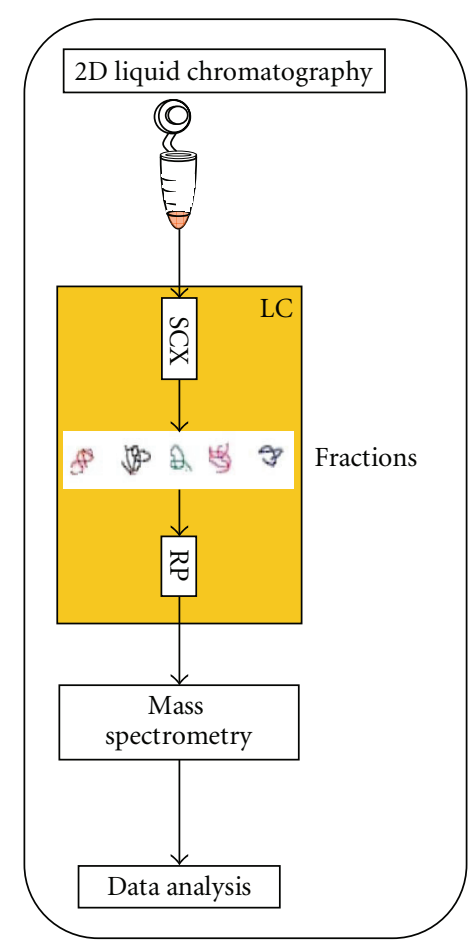

(b)

FIgURE 4: (a) Proteins from mixtures are analysed using 2D PAGE followed by mass spectrometry. The identification of proteins is from the spectra produced from the peptides of the digested proteins which provide a unique fingerprint from the peptides. Protein microarrays consist of different protein binding molecules, for example, antibodies at separate locations on a chip made from glass or silicone to capture molecules to detect proteins from cell lysate solutions. The proteins can be visualised using a fluorometric or colorimetric analysis or the spots can be analysed by mass spectrometry. (b) Multidimensional liquid chromatography mass spectrometry (LC-MS) involves digestion of a complex protein sample initially using a strong cation exchange (SCX) column. The resulting peptides are separated by LC into fractions. The resulting fractions are separated further using a reversed-phase (RP) column and characterized by mass spectrometry using shotgun sequencing of the peptides.

detect proteins from cell lysate solutions [43]. This technique has high sensitivity and can simultaneously analyse thousands of proteins within a single experiment. Antibody specific profiling allows analysis of complex protein mixtures; however this limits the technique to the detection of specific targets and does not give a complete view of the proteins involved in a process.

\section{Bottom-Up Approaches}

Multidimensional liquid chromatography mass spectrometry (LC-MS) involves digestion of a complex protein sample. The resulting peptides are separated by chromatography into fractions. The resulting fractions are separated further by chromatography and characterized by mass spectrometry using shotgun sequencing of the peptides, that is, the peptide fractions are reassembled to give the overall sequence to generate protein lists. This technique is almost entirely automated and has increased sensitivity to enhance the detection of low-abundance proteins. It has a greater success in the identification of proteins in very complex mixtures $[42,44,45]$. However, analysis times can be long, and the resulting data is complex. Also high abundance proteins tend to confound smaller proteins in the analysis.

\section{Western Blotting}

An alternative protein analysis technique is western blotting in which proteins in CSF can be confirmed using specific antibodies. This technique allows specific targets to be compared between sample groups. It relies on previous identification of proteins of interest.

\section{Nonprotein Techniques}

Glycan structures present on the cell wall such as lipoteichioic acid (LTA) and peptidoglycan (PG) play an important role in inflammation but are not accessible to proteomic approaches. Glycans can be measured using specialist techniques for example the silkworm larvae (SLP) test was developed to analyse PG in CSF [46]. Similarly LTA can be measured using an enzyme immunoassay [47].

\section{Host and Pathogen Proteins}

Proteomic comparisons of infected and normal CSF can be expected to differ in the concentration of both pneumococcal proteins and host proteins. Identification of pneumococcal proteins associated with poor outcome may suggest either 
TABLE 1: The cell wall of $S$. pneumoniae has a diverse protein population, and pathogenic expression of pneumoccal proteins are associated with adherence to and colonisation of mucosal surfaces, resistance to specific and nonspecific host defences, penetration and invasion of host tissues, and generation of tissue damage mediated either directly by toxins or indirectly via inflammatory responses.

\begin{tabular}{|c|c|c|c|}
\hline Protein & Description & Action & References \\
\hline LytA & $\begin{array}{l}\text { Enzyme required during } \\
\text { cell division }\end{array}$ & $\begin{array}{l}\text { Hydrolyses amide bonds between muramic acid } \\
\text { and L-Alanine residues }\end{array}$ & {$[48,49]$} \\
\hline PspA & $\begin{array}{l}\text { Ranges from } 67-99 \mathrm{kDa} \\
\text { in size. Anchored to the } \\
\text { outer layer of the plasma } \\
\text { membrane }\end{array}$ & $\begin{array}{l}\text { Reduces complement mediated clearance and } \\
\text { phagocytosis of } S \text {. pneumoniae. Inhibits } \\
\text { complement activation, thereby limiting } \\
\text { opsonisation of pathogens by complement } \\
\text { protein } 3 \text { (C3) }\end{array}$ & {$[50]$} \\
\hline $\begin{array}{l}\text { Pneumococcal } \\
\text { histidine triad } \\
\text { (Pht) }\end{array}$ & $\begin{array}{l}\text { Novel family of cell sur- } \\
\text { face-exposed pneumoc- } \\
\text { occal proteins }\end{array}$ & $\begin{array}{l}\text { Consists of PhtA, PhtB, PhtD, and PhtE. PhtB } \\
\text { and PhtE. Induces antibodies capable of } \\
\text { protecting mice against pneumococcal sepsis } \\
\text { and death }\end{array}$ & {$[51,52]$} \\
\hline PspC & $\begin{array}{l}\text { Surface protein choline } \\
\text { binding domain has } 90 \% \\
\text { homology to PspA }\end{array}$ & $\begin{array}{l}\text { Binds to the polymeric immunoglobulin } \\
\text { receptor and mediates invasion across human } \\
\text { nasopharyngeal epithelial cells }\end{array}$ & {$[53,54]$} \\
\hline $\begin{array}{l}\text { Neuraminidases, } \\
\text { for example, NanA } \\
\text { and NanB }\end{array}$ & $\begin{array}{l}\text { Cleaves terminal sialic } \\
\text { acid residues from a wi- } \\
\text { de variety of glycolipids, } \\
\text { glycoproteins, and oligo- } \\
\text { saccharides }\end{array}$ & $\begin{array}{l}\text { The precise role of NanA in pneumococcal } \\
\text { disease is unknown. The relative contribution of } \\
\text { NanB to disease has not been reported in either } \\
\text { a sepsis or pneumonia model }\end{array}$ & {$[55,56]$} \\
\hline $\begin{array}{l}\text { Heat shock } \\
\text { proteins }\end{array}$ & $\begin{array}{l}\text { A highly conserved set of } \\
\text { proteins }\end{array}$ & $\begin{array}{l}\text { Heat stress proteins are produced after } \\
\text { penetration from the nasal mucosa }\left(30 \text { to } 34^{\circ} \mathrm{C}\right) \\
\text { into the blood and/or meninges }\left(37^{\circ} \mathrm{C}\right)\end{array}$ & {$[39]$} \\
\hline $\begin{array}{l}\text { Hyaluronate lyase } \\
\text { (Hyal) }\end{array}$ & $\begin{array}{l}\text { Covalently linked to the } \\
\text { cross-bridges of the cell } \\
\text { wall peptidoglycan }\end{array}$ & $\begin{array}{l}\text { Degrades essential components of the host's } \\
\text { extracellular matrix (ECM), hyaluronan (HA), } \\
\text { unsulfated chondroitin }(\mathrm{CH}) \text {, and certain } \\
\text { chondroitin sulfates (CHSs) }\end{array}$ & {$[57]$} \\
\hline $\begin{array}{l}\text { Pneumococcal } \\
\text { surface antigen A } \\
\text { (PsaA) }\end{array}$ & $\begin{array}{l}34.5 \mathrm{kDa} \text { protein covale- } \\
\text { ntly anchored to the cell } \\
\text { membrane }\end{array}$ & $\begin{array}{l}\text { Belongs to an ATP binding cassette-(ABC-) type } \\
\text { transport system and constitutes the } \\
\text { extracellular component responsible for solute } \\
\text { (metal) binding }\end{array}$ & {$[58]$} \\
\hline $\begin{array}{l}\text { Pneumolysin } \\
\text { (Hemolysin or Ply) }\end{array}$ & $53-\mathrm{kDa}$ protein & $\begin{array}{l}\text { Binds to membrane cholesterol and inserts the } \\
\text { toxin into the lipid bilayer. Induces leakage of } \\
\text { solutes }\end{array}$ & {$[59]$} \\
\hline $\begin{array}{l}\text { Penicillin-binding } \\
\text { proteins (PBPs) }\end{array}$ & $\begin{array}{l}\text { S. pneumoniae carry a re- } \\
\text { latively simple set of six } \\
\text { PBPs }\end{array}$ & $\begin{array}{l}\text { Catalyse the polymerisation of glycan chains and } \\
\text { transpeptidation of pentapeptidic moieties } \\
\text { within the structure of the peptidoglycan }\end{array}$ & {$[60]$} \\
\hline $\begin{array}{l}\text { Pneumococcal iron } \\
\text { uptake (Piu) and } \\
\text { iron acquisition } \\
\text { (Pia) }\end{array}$ & $\begin{array}{l}\text { Lipoprotein components } \\
\text { of iron } \mathrm{ABC} \text { transport } \\
\text { systems }\end{array}$ & $\begin{array}{l}\text { Essential for iron uptake. Pia is the dominant } \\
\text { iron transporter. PiuA and PiaA have been } \\
\text { shown to be present in all pneumococcal species }\end{array}$ & {$[61]$} \\
\hline
\end{tabular}

therapeutic possibilities or vaccine candidates. Host proteins associated with poor outcome may suggest pathways amenable to immunomodulation or therapeutic intervention.

\section{Pneumococcal Proteins}

The cell wall of S. pneumoniae has a diverse protein population, and pathogenic expression of pneumoccal proteins is associated with adherence to and colonisation of mucosal surfaces, resistance to specific and nonspecific host defences, penetration, and invasion of host tissues, and generation of tissue damage mediated either directly by toxins or indirectly via inflammatory responses as summarised in Table 1. All the proteins listed in Table 1 have been described in experimental studies including animal models of meningitis and have been found to exhibit an effect on inflammation, and toxicity for example $\mathrm{N}$-acetylmuramoyl-L-alanine-amidase (LytA) is an autolytic enzyme required during cell division. Its role in pneumococcal meningitis is unknown but has been shown in various animal models to mediate toxicity and inflammation [48]. Proteins such as pneumolysin can stimulate the host response and also enter cells though pore formation. It has the ability to trigger apoptosis on entering cells by destruction of the mitochondria [48]. In addition oxidising components such as hydrogen peroxide can also trigger 
TABLE 2: The host immune response will most likely make up the majority of proteins present in the CSF because these proteins will include host immune response factors such as complement and cytokines as well as specific immunoglobulins and proteins from serum leaking to the CSF as a result of the blood brain barrier breakdown.

\begin{tabular}{|c|c|c|c|}
\hline Protein & Description & Action & References \\
\hline $\begin{array}{l}\text { Complement } \\
\text { components, for } \\
\text { example, C3b, } \\
\text { iC3b, or C4b } \\
\text { (CR1, CR3) }\end{array}$ & $\begin{array}{l}\text { Consists of a number of } \\
\text { small proteins found in the } \\
\text { blood, normally circulating } \\
\text { as inactive zymogens }\end{array}$ & $\begin{array}{l}\text { Help to clear pathogens from an } \\
\text { organism }\end{array}$ & {$[62]$} \\
\hline IL-6 & $\begin{array}{l}\text { A proinflammatory cytok- } \\
\text { ine }\end{array}$ & $\begin{array}{l}\text { Secreted by } \mathrm{T} \text { cells and } \\
\text { macrophages to stimulate } \\
\text { immune response to trauma, } \\
\text { leading to inflammation }\end{array}$ & {$[63]$} \\
\hline $\begin{array}{l}\text { Interleukin-1 } \\
\text { (IL-1) }\end{array}$ & $\begin{array}{l}\text { A superfamily consisiting of } \\
\text { IL- } 1 \alpha \text {, IL- } 1 \beta \text {, and the IL- } \\
1 \text { receptor antagonist (IL- } \\
1 \mathrm{RA} \text { ) }\end{array}$ & $\begin{array}{l}\text { They control lymphocytes. IL- } 1 \alpha \\
\text { and IL- } 1 \beta \text { are produced by } \\
\text { macrophages, monocytes, and } \\
\text { dendritic cells }\end{array}$ & {$[64]$} \\
\hline $\operatorname{IgG}$ & $\begin{array}{l}\text { The most abundant imm- } \\
\text { unoglobulin. Equally dis- } \\
\text { tributed in blood and in } \\
\text { tissue liquids }\end{array}$ & $\begin{array}{l}\text { Activates complement (classic } \\
\text { pathway), opsonization for } \\
\text { phagocytosis, and neutralisation } \\
\text { of their toxins }\end{array}$ & {$[65]$} \\
\hline
\end{tabular}

TABLE 3: Poteins associated with the apoptotic pathway could potentially be discovered in the CSF after cell death. The levels of these proteins can be expected to increase during pneumococcal meningitis as a result of both the inflammatory response and the release of pneumococcal proteins.

\begin{tabular}{|c|c|c|c|}
\hline Protein & Description & Action & References \\
\hline
\end{tabular}

Cytochrome C (Cyt C)

Tumour necrosis factor (TNF- $\alpha$ )

Caspases

Fas

Fas-associated death domain protein (FADD)

BAX

Apoptosis inducing factor (AIF)
A small heme protein found loosely associated with the inner membrane of the mitochondrion

TNF acts via the TNF receptor (TNF-R) and is part of the extrinsic pathway for triggering apoptosis

Proteases, which exist as inactive proenzymes

Ligand which associated with the forms the Death Inducing Signalling Complex (DISC) upon ligand binding

An adaptor molecule that bridges the Fas-receptor, and other death receptors, to caspase- 8 through its death domain

A proapoptotic member of the $\mathrm{Bcl}$ 2 protein family

A flavoprotein found in the mitochondrial intermembrane space in healthy cells
Cause ER calcium release. The overall increase in calcium triggers a massive release of additional cyt c, which then acts in the positive feedback loop to maintain ER calcium release through the inositol 3 phosphate receptors. This release in turn activates caspase- 9

TNF-R associates with procaspases through adapter proteins (FADD, TRADD, etc.)

Play essential roles in apoptosis (programmed cell death) and inflammation

Fas pathway is sufficient to induce complete apoptosis in certain cell types through DISC assembly and subsequent caspase- 8 activation

Forms the death inducing signalling complex (DISC) during apoptosis

Activated Bax forms an oligomeric pore in the outer membrane

Essential for nuclear disassembly in apoptotic cells
[10] 
apoptosis and necrosis. Both pneumolysin and autolysin have been shown to play a crucial role in the pathogenesis of pneumococcal meningitis in an adult rat model of meningitis [69]. Neuraminidases are a group of enzymes which can cleave terminal sialic acid residues from a wide variety of glycan structures [55]. The pneumococcus produces two distinct neuraminidases, $N$-acetylneuraminic acid (NanA) and endo- $\beta-1,4-N$-acetylglucosaminidase (NanB) $[70,71]$. There are several conflicting publications on the precise role of NanA in pneumococcal disease; however an Otitis media chinchilla model that revealed that NanA-deficient pneumococci are significantly less able to colonise and persist in the nasopharynx and middle ear than NanA-sufficient wild-type pneumococci [56]. The relative contribution of $\mathrm{NanB}$ to disease has not been reported in either a sepsis or pneumonia model.

\section{Host Proteins}

The host immune response will most likely make up the majority of proteins present in the CSF because these proteins will include host immune response factors such as complement and cytokines as well as specific immunoglobulins and proteins from serum leaking to the CSF as a result of the blood brain barrier breakdown (Table 2). These will include signalling molecules such as tumour necrosis factor alpha (TNF- $\alpha)$ [72], Fas and Fas-associated death domain (FADD) protein, (Table 3) [68]. These proteins can lead to apoptosis through activation of transmembrane death receptors, such as Fas which causes receptors to aggregate together on the cell surface. This activates the adaptor protein Fas-associated death domain (FADD) protein, which in turn activates caspase- 8 , an initiator protein, to form a signal complex. This complex is now able to directly activate caspase-3, an effector protein, to initiate degradation of the cell. Active caspase- 8 can also cleave BID protein to tBID, which acts as a signal on the membrane of mitochondria to facilitate the release of cytochrome $\mathrm{c}$ in the intrinsic pathway. The mitochondrial stress pathway is initiated when a stress signal is activated, proapoptotic proteins in the cytoplasm, BAX, and BID stimulate the rupture of the mitochondria. The release of mitochondrial content is aided by the protein BAK. In the caspase dependant pathway, cytochrome $\mathrm{c}$ released from the mitochondria forms a complex in the cytoplasm with adenosine triphosphate (ATP) and apoptotic protease activating factor-1 (Apaf-1). This complex activates caspase-9, an initiator protein. In return, the activated caspase- 9 works together with the complex of cytochrome c, ATP, and Apaf-1 to form an apoptosome, which in turn activates caspase-3, the effector protein that initiates degradation. The caspase independent pathway (pyknosis) is a result of apoptosis inducing factor (AIF). The necrotic pathway is activated in severe meningitis. Alterations in the concentration of cytoplasmic calcium signal the mobilisation of executioner cathepsin proteases and other hydrolases, through calpain activation. Calpains have been implicated in the activation of proapoptotic caspase proteases; hence the later steps of necrosis correlate with the later steps of apoptosis.
Proteomic analysis of CSF will allow dominant pathways to be determined and the relative importance of apoptosis and necrosis to be estimated in patients and neurological damage.

\section{Conclusion}

A novel therapy is needed to improve outcome in meningitis. Animal models that suggest mechanism of neuronal injury are amenable to therapy. Critical information is still needed to move from animal models into human trials. This pivotal information could be provided by proteomic analysis of CSF.

\section{Acknowledgments}

This work was supported by the Wellcome Trust (Grant no. 061231 awarded to Dr. S. B. Gordon) and LSTM Studentship (awarded to U.R. Goonetilleke).

\section{References}

[1] K.-J. Lee, S.-M. Bae, M.-R. Lee, S.-M. Yeon, Y.-H. Lee, and K.-S. Kim, "Proteomic analysis of growth phase-dependent proteins of Streptococcus pneumoniae," Proteomics, vol. 6, no. 4, pp. 1274-1282, 2006.

[2] S. B. Gordon, A. L. Walsh, M. Chaponda, et al., "Bacterial meningitis in Malawian adults: pneumococcal disease is common, severe, and seasonal," Clinical Infectious Diseases, vol. 31 , no. 1 , pp. $53-57,2000$.

[3] D. M. Cardozo, C. M. C. Nascimento-Carvalho, F. R. Souza, and N. M. S. Silva, "Nasopharyngeal colonization and penicillin resistance among pneumococcal strains: a worldwide 2004 update," Brazilian Journal of Infectious Diseases, vol. 10, no. 4, pp. 293-303, 2006.

[4] A. Roche, P. T. Heath, M. Sharland, et al., "Prevalence of nasopharyngeal carriage of pneumococcus in preschool children attending day care in London," Archives of Disease in Childhood, vol. 92, no. 12, pp. 1073-1076, 2007.

[5] P. C. Hill, A. Akisanya, K. Sankareh, et al., "Nasopharyngeal carriage of Streptococcus pneumoniae in Gambian villagers," Clinical Infectious Diseases, vol. 43, no. 6, pp. 673-679, 2006.

[6] S. B. Gordon, M. Chaponda, A. L. Walsh, et al., "Pneumococcal disease in HIV-infected Malawian adults: acute mortality and long-term survival," AIDS, vol. 16, no. 10, pp. 1409-1417, 2002.

[7] D. van de Beek, J. de Gans, A. R. Tunkel, and E. F. M. Wijdicks, "Community-acquired bacterial meningitis in adults," The New England Journal of Medicine, vol. 354, no. 1, pp. 44-53, 2006.

[8] J. N. Weiser, D. Bae, H. Epino, et al., "Changes in availability of oxygen accentuate differences in capsular polysaccharide expression by phenotypic variants and clinical isolates of Streptococcus pneumoniae," Infection and Immunity, vol. 69, no. 9 , pp. 5430-5439, 2001.

[9] D. M. Moody, "The blood-brain barrier and blood-cerebral spinal fluid barrier," Seminars in Cardiothoracic and Vascular Anesthesia, vol. 10, no. 2, pp. 128-131, 2006.

[10] D. Bermpohl, A. Halle, D. Freyer, et al., "Bacterial programmed cell death of cerebral endothelial cells involves dual death pathways," The Journal of Clinical Investigation, vol. 115, no. 6, pp. 1607-1615, 2005. 
[11] J. R. Weber and E. I. Tuomanen, "Cellular damage in bacterial meningitis: an interplay of bacterial and host driven toxicity," Journal of Neuroimmunology, vol. 184, no. 1-2, pp. 45-52, 2007.

[12] F. W. van Ginkel, J. R. McGhee, J. M. Watt, A. CamposTorres, L. A. Parish, and D. E. Briles, "Pneumococcal carriage results in ganglioside-mediated olfactory tissue infection," Proceedings of the National Academy of Sciences of the United States of America, vol. 100, supplement 2, pp. 14363-14367, 2003.

[13] A. Marra and D. Brigham, "Streptococcus pneumoniae causes experimental meningitis following intranasal and otitis media infections via a nonhematogenous route," Infection and Immunity, vol. 69, no. 12, pp. 7318-7325, 2001.

[14] H. M. Marriott and D. H. Dockrell, "Streptococcus pneumoniae: the role of apoptosis in host defense and pathogenesis," The International Journal of Biochemistry \& Cell Biology, vol. 38, no. 11, pp. 1848-1854, 2006.

[15] J. Zweigner, S. Jackowski, S. H. Smith, M. van der Merwe, J. R. Weber, and E. I. Tuomanen, "Bacterial inhibition of phosphatidylcholine synthesis triggers apoptosis in the brain," Journal of Experimental Medicine, vol. 200, no. 1, pp. 99-106, 2004.

[16] U. Koedel, W. M. Scheld, and H.-W. Pfister, "Pathogenesis and pathophysiology of pneumococcal meningitis," The Lancet Infectious Diseases, vol. 2, no. 12, pp. 721-736, 2002.

[17] R. Nau and W. Brück, "Neuronal injury in bacterial meningitis: mechanisms and implications for therapy," Trends in Neurosciences, vol. 25, no. 1, pp. 38-45, 2002.

[18] A. Spreer, J. Gerber, D. Baake, M. Hanssen, G. Huether, and R. Nau, "Antiinflammatory but no neuroprotective effects of melatonin under clinical treatment conditions in rabbit models of bacterial meningitis," Journal of Neuroscience Research, vol. 84, no. 7, pp. 1575-1579, 2006.

[19] J. S. Braun, R. Novak, K.-H. Herzog, S. M. Bodner, J. L. Cleveland, and E. I. Tuomanen, "Neuroprotection by a caspase inhibitor in acute bacterial meningitis," Nature Medicine, vol. 5, no. 3, pp. 298-302, 1999.

[20] G. Zysk, W. Brück, J. Gerber, Y. Brück, H. W. Prange, and R. Nau, "Anti-inflammatory treatment influences neuronal apoptotic cell death in the dentate gyrus in experimental pneumococcal meningitis," Journal of Neuropathology and Experimental Neurology, vol. 55, no. 6, pp. 722-728, 1996.

[21] L. Mitchell, S. H. Smith, J. S. Braun, K.-H. Herzog, J. R. Weber, and E. I. Tuomanen, "Dual phases of apoptosis in pneumococcal meningitis," The Journal of Infectious Diseases, vol. 190, no. 11, pp. 2039-2046, 2004.

[22] Y.-D. Bifrare, J. Kummer, P. Joss, M. G. Täuber, and S. L. Leib, "Brain-derived neurotrophic factor protects against multiple forms of brain injury in bacterial meningitis," The Journal of Infectious Diseases, vol. 191, no. 1, pp. 40-45, 2005.

[23] Y.-D. Bifrare, C. Gianinazzi, H. Imboden, S. L. Leib, and M. G. Täuber, "Bacterial meningitis causes two distinct forms of cellular damage in the hippocampal dentate gyrus in infant rats," Hippocampus, vol. 13, no. 4, pp. 481-488, 2003.

[24] D. Grandgirard, O. Steiner, M. G. Täuber, and S. L. Leib, "An infant mouse model of brain damage in pneumococcal meningitis," Acta Neuropathologica, vol. 114, no. 6, pp. 609617, 2007.

[25] D. van de Beek, J. de Gans, L. Spanjaard, M. Weisfelt, J. B. Reitsma, and M. Vermeulen, "Clinical features and prognostic factors in adults with bacterial meningitis," The New England Journal of Medicine, vol. 351, no. 18, pp. 1849-1859, 2004.

[26] J. S. Braun, O. Hoffmann, M. Schickhaus, et al., "Pneumolysin causes neuronal cell death through mitochondrial damage," Infection and Immunity, vol. 75, no. 9, pp. 4245-4254, 2007.

[27] D. Kögel, B. Svensson, E. Copanaki, et al., "Induction of transcription factor CEBP homology protein mediates hypoglycaemia-induced necrotic cell death in human neuroblastoma cells," Journal of Neurochemistry, vol. 99, no. 3, pp. 952-964, 2006.

[28] J. Niquet, D.-W. Seo, and C. G. Wasterlain, "Mitochondrial pathways of neuronal necrosis," Biochemical Society Transactions, vol. 34, no. 6, pp. 1347-1351, 2006.

[29] M. G. Tauber, H. Khayam-Bashi, and M. A. Sande, "Effects of ampicillin and corticosteroids on brain water content, cerebrospinal fluid pressure, and cerebrospinal fluid lactate levels in experimental pneumococcal meningitis," The Journal of Infectious Diseases, vol. 151, no. 3, pp. 528-534, 1985.

[30] J. de Gans and D. van de Beek, "Dexamethasone in adults with bacterial meningitis," The New England Journal of Medicine, vol. 347, no. 20, pp. 1549-1556, 2002.

[31] E. M. Molyneux, A. L. Walsh, H. Forsyth, et al., "Dexamethasone treatment in childhood bacterial meningitis in Malawi: a randomised controlled trial," The Lancet, vol. 360, no. 9328, pp. 211-218, 2002.

[32] M. Scarborough, S. B. Gordon, C. J. M. Whitty, et al., "Corticosteroids for bacterial meningitis in adults in subSaharan Africa," The New England Journal of Medicine, vol. 357, no. 24, pp. 2441-2450, 2007.

[33] X. A. Álvarez, C. Sampedro, R. Lozano, and R. Cacabelos, "Citicoline protects hippocampal neurons against apoptosis induced by brain $\beta$-amyloid deposits plus cerebral hypoperfusion in rats," Methods and Findings in Experimental and Clinical Pharmacology, vol. 21, no. 8, pp. 535-540, 1999.

[34] D. Leppert, S. L. Leib, C. Grygar, K. M. Miller, U. B. Schaad, and G. A. Holländer, "Matrix metalloproteinase (MMP)-8 and MMP-9 in cerebrospinal fluid during bacterial meningitis: association with blood-brain barrier damage and neurological sequelae," Clinical Infectious Diseases, vol. 31, no. 1, pp. 80-84, 2000.

[35] S. Starckx, P. E. van den Steen, R. Verbeek, J. M. van Noort, and G. Opdenakker, "A novel rationale for inhibition of gelatinase B in multiple sclerosis: MMP-9 destroys $\alpha \mathrm{B}-$ crystallin and generates a promiscuous T cell epitope," Journal of Neuroimmunology, vol. 141, no. 1-2, pp. 47-57, 2003.

[36] P. Ciborowski, Y. Enose, A. MacK, M. Fladseth, and H. E. Gendelman, "Diminished matrix metalloproteinase 9 secretion in human immunodeficiency virus-infected mononuclear phagocytes: modulation of innate immunity and implications for neurological disease," Journal of Neuroimmunology, vol. 157, no. 1-2, pp. 11-16, 2004.

[37] N. Khidekel and L. C. Hsieh-Wilson, "A 'molecular switchboard'-covalent modifications to proteins and their impact on transcription," Organic and Biomolecular Chemistry, vol. 2, no. 1, pp. 1-7, 2004.

[38] H. B. Armah, N. O. Wilson, B. Y. Sarfo, et al., "Cerebrospinal fluid and serum biomarkers of cerebral malaria mortality in Ghanaian children," Malaria Journal, vol. 6, article 147, pp. 117, 2007.

[39] A. V. Mudaliar, R. S. Kashyap, H. J. Purohit, G. M. Taori, and H. F. Daginawala, "Detection of $65 \mathrm{kD}$ heat shock protein in 
cerebrospinal fluid of tuberculous meningitis patients," $B M C$ Neurology, vol. 6, article 34, pp. 1-7, 2006.

[40] V. Lehmensiek, S. D. Süssmuth, J. Brettschneider, et al., "Proteome analysis of cerebrospinal fluid in Guillain-Barré syndrome (GBS)," Journal of Neuroimmunology, vol. 185, no. 1-2, pp. 190-194, 2007.

[41] K. A. Carlson, P. Ciborowski, C. N. Schellpeper, et al., "Proteomic fingerprinting of HIV-1-infected human monocytederived macrophages: a preliminary report," Journal of Neuroimmunology, vol. 147, no. 1-2, pp. 35-42, 2004.

[42] G. Chambers, L. Lawrie, P. Cash, and G. I. Murray, "Proteomics: a new approach to the study of disease," Journal of Pathology, vol. 192, no. 3, pp. 280-288, 2000.

[43] S. Kastenbauer, B. Angele, B. Sporer, H.-W. Pfister, and U. Koedel, "Patterns of protein expression in infectious meningitis: a cerebrospinal fluid protein array analysis," Journal of Neuroimmunology, vol. 164, no. 1-2, pp. 134-139, 2005.

[44] R. Aebersold and M. Mann, "Mass spectrometry-based proteomics," Nature, vol. 422, no. 6928, pp. 198-207, 2003.

[45] J. S. Andersen and M. Mann, "Functional genomics by mass spectrometry," FEBS Letters, vol. 480, no. 1, pp. 25-31, 2000.

[46] K. Inada, K. Takahashi, S. Ichinohe, et al., "A silkworm larvae plasma test for detecting peptidoglycan in cerebrospinal fluid is useful for the diagnosis of bacterial meningitis," Microbiology and Immunology, vol. 47, no. 10, pp. 701-707, 2003.

[47] O. Schneider, U. Michel, G. Zysk, O. Dubuis, and R. Nau, "Clinical outcome in pneumococcal meningitis correlates with CSF lipoteichoic acid concentrations," Neurology, vol. 53, no. 7, pp. 1584-1587, 1999.

[48] P. Balachandran, S. K. Hollingshead, J. C. Paton, and D. E. Briles, "The autolytic enzyme lytA of Streptococcus pneumoniae is not responsible for releasing pneumolysin," Journal of Bacteriology, vol. 183, no. 10, pp. 3108-3116, 2001.

[49] R. A. Hirst, B. Gosai, A. Rutman, et al., "Streptococcus pneumoniae deficient in pneumolysin or autolysin has reduced virulence in meningitis," The Journal of Infectious Diseases, vol. 197, no. 5, pp. 744-751, 2008.

[50] B. Ren, A. J. Szalai, S. K. Hollingshead, and D. E. Briles, "Effects of PspA and antibodies to PspA on activation and deposition of complement on the pneumococcal surface," Infection and Immunity, vol. 72, no. 1, pp. 114-122, 2004.

[51] A. Riboldi-Tunnicliffe, N. W. Isaacs, and T. J. Mitchell, " $1.2 \AA$ crystal structure of the S. pneumoniae PhtA histidine triad domain a novel zinc binding fold," FEBS Letters, vol. 579, no. 24, pp. 5353-5360, 2005.

[52] J. E. Adamou, J. H. Heinrichs, A. L. Erwin, et al., "Identification and characterization of a novel family of pneumococcal proteins that are protective against sepsis," Infection and Immunity, vol. 69, no. 2, pp. 949-958, 2001.

[53] S. Dave, S. Carmicle, S. Hammerschmidt, M. K. Pangburn, and L. S. McDaniel, "Dual roles of PspC, a surface protein of Streptococcus pneumoniae, in binding human secretory IgA and factor H," Journal of Immunology, vol. 173, no. 1, pp. 471$477,2004$.

[54] A. R. Kerr, G. K. Paterson, J. McCluskey, et al., “The contribution of PspC to pneumococcal virulence varies between strains and is accomplished by both complement evasion and complement-independent mechanisms," Infection and Immunity, vol. 74, no. 9, pp. 5319-5324, 2006.

[55] J. C. Paton, P. W. Andrew, G. J. Boulnois, and T. J. Mitchell, "Molecular analysis of the pathogenicity of Streptococcus pneumoniae: the role of pneumococcal proteins," Annual Review of Microbiology, vol. 47, pp. 89-115, 1993.

[56] H. H. Tong, L. E. Blue, M. A. James, and T. F. DeMaria, "Evaluation of the virulence of a Streptococcus pneumoniae neuraminidase-deficient mutant in nasopharyngeal colonization and development of otitis media in the chinchilla model," Infection and Immunity, vol. 68, no. 2, pp. 921-924, 2000.

[57] D. J. Rigden, J. E. Littlejohn, H. V. Joshi, B. L. de Groot, and M. J. Jedrzejas, "Alternate structural conformations of Streptococcus pneumoniae hyaluronan lyase: insights into enzyme flexibility and underlying molecular mechanism of action," Journal of Molecular Biology, vol. 358, no. 4, pp. 11651178, 2006.

[58] M. J. Jedrzejas, "Pneumococcal virulence factors: structure and function," Microbiology and Molecular Biology Reviews, vol. 65, no. 2, pp. 187-207, 2001.

[59] R. A. Hirst, B. Gosai, A. Rutman, et al., "Streptococcus pneumoniae deficient in pneumolysin or autolysin has reduced virulence in meningitis," The Journal of Infectious Diseases, vol. 197, no. 5, pp. 744-751, 2008.

[60] C. Sauve, E. Azoulay-Dupuis, P. Moine, et al., "Efficacies of cefotaxime and ceftriaxone in a mouse model of pneumonia induced by two penicillin- and cephalosporin-resistant strains of Streptococcus pneumoniae," Antimicrobial Agents and Chemotherapy, vol. 40, no. 12, pp. 2829-2834, 1996.

[61] J. S. Brown, A. D. Ogunniyi, M. C. Woodrow, D. W. Holden, and J. C. Paton, "Immunization with components of two iron uptake $\mathrm{ABC}$ transporters protects mice against systemic Streptococcus pneumoniae infection," Infection and Immunity, vol. 69, no. 11, pp. 6702-6706, 2001.

[62] E. J. Brown, K. A. Joiner, R. M. Cole, and M. Berger, "Localization of complement component 3 on Streptococcus pneumoniae: anti-capsular antibody causes complement deposition on the pneumococcal capsule," Infection and Immunity, vol. 39, no. 1, pp. 403-409, 1983.

[63] T. van der Poll, C. V. Keogh, X. Guirao, W. A. Buurman, M. Kopf, and S. F. Lowry, "Interleukin-6 gene-deficient mice show impaired defense against pneumococcal pneumonia," The Journal of Infectious Diseases, vol. 176, no. 2, pp. 439-444, 1997.

[64] C. A. Dinarello, "The interleukin-1 family: 10 years of discovery," The FASEB Journal, vol. 8, no. 15, pp. 1314-1325, 1994.

[65] P. W. H. I. Parren, P. A. M. Warmerdam, L. C. M. Boeije, et al., "On the interaction of IgG subclasses with the low affinity Fc $\gamma$ RIIa (CD32) on human monocytes, neutrophils, and platelets. Analysis of a functional polymorphism to human IgG2," The Journal of Clinical Investigation, vol. 90, no. 4, pp. 1537-1546, 1992.

[66] V. P. Skulachev, "Cytochrome c in the apoptotic and antioxidant cascades," FEBS Letters, vol. 423, no. 3, pp. 275-280, 1998.

[67] R. M. Locksley, N. Killeen, and M. J. Lenardo, "The TNF and TNF receptor superfamilies: integrating mammalian biology," Cell, vol. 104, no. 4, pp. 487-501, 2001.

[68] R. Paul, B. Angele, B. Sporer, H.-W. Pfister, and U. Koedel, "Inflammatory response during bacterial meningitis is unchanged in Fas- and Fas ligand-deficient mice," Journal of Neuroimmunology, vol. 152, no. 1-2, pp. 78-82, 2004.

[69] R. A. Hirst, B. Gosai, A. Rutman, et al., "Streptococcus pneumoniae deficient in pneumolysin or autolysin has reduced virulence in meningitis," The Journal of Infectious Diseases, vol. 197, no. 5, pp. 744-751, 2008. 
[70] A. M. Berry, R. A. Lock, and J. C. Paton, "Cloning and characterization of nanB, a second Streptococcus pneumoniae neuraminidase gene, and purification of the Nanb enzyme from recombinant Escherichia coli," Journal of Bacteriology, vol. 178, no. 16, pp. 4854-4860, 1996.

[71] M. Camara, G. J. Boulnois, P. W. Andrew, and T. J. Mitchell, "A neuraminidase from Streptococcus pneumoniae has the features of a surface protein," Infection and Immunity, vol. 62, no. 9, pp. 3688-3695, 1994.

[72] M. Letiembre, H. Echchannaoui, F. Ferracin, S. Rivest, and R. Landmann, "Toll-like receptor-2 deficiency is associated with enhanced brain TNF gene expression during pneumococcal meningitis," Journal of Neuroimmunology, vol. 168, no. 1-2, pp. 21-33, 2005. 


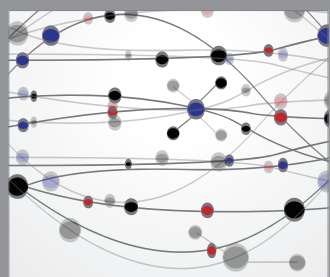

The Scientific World Journal
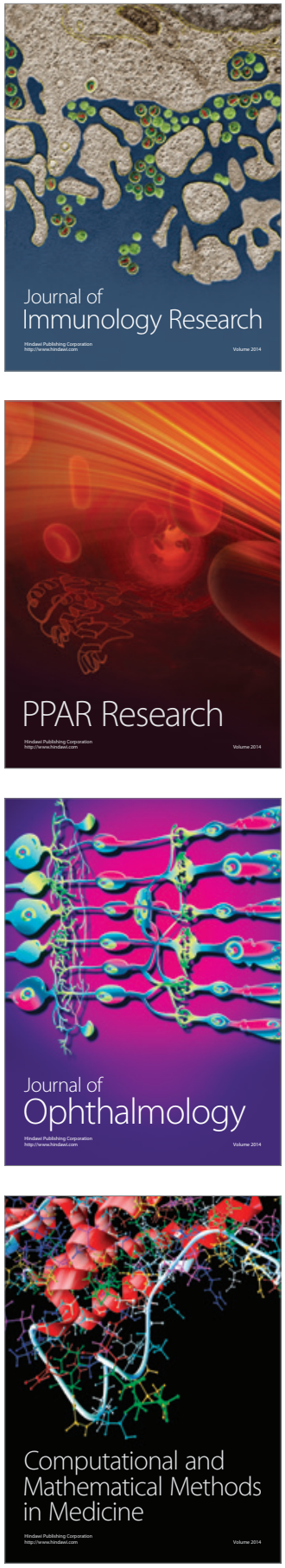

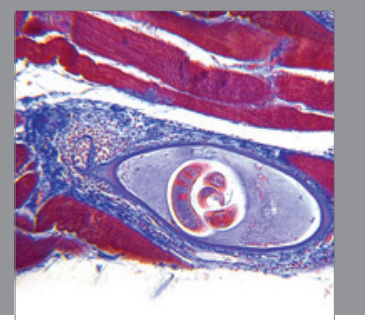

Gastroenterology

Research and Practice
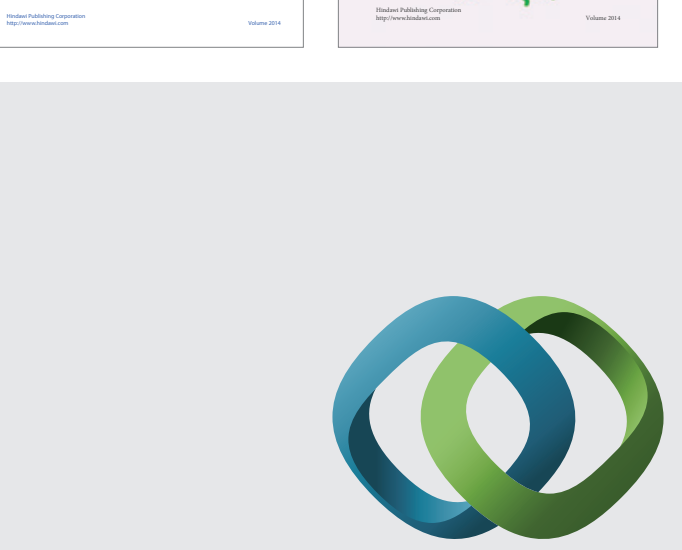

\section{Hindawi}

Submit your manuscripts at

http://www.hindawi.com
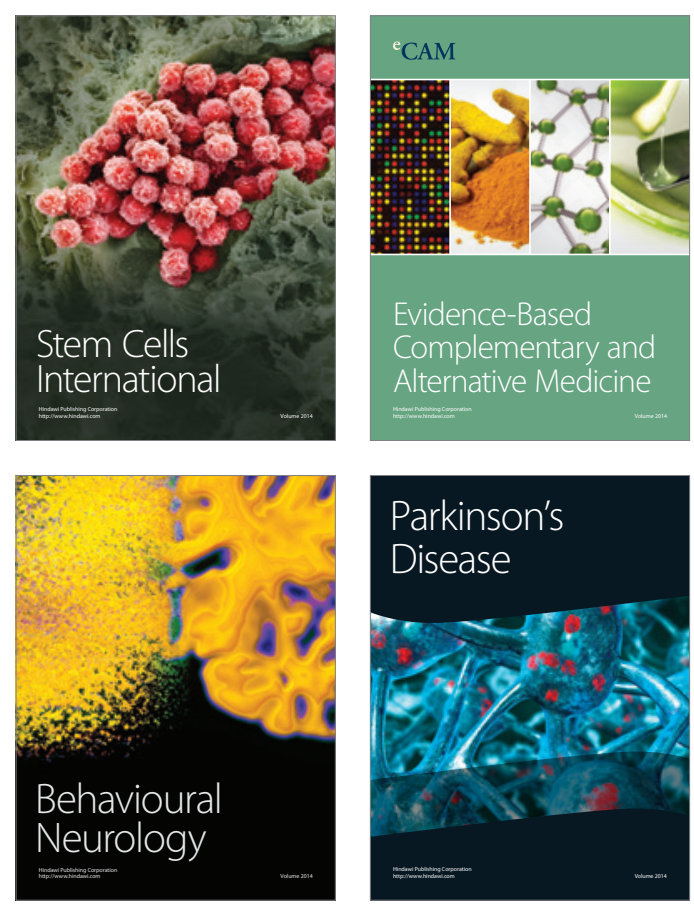

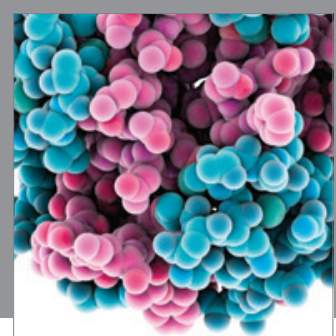

Journal of
Diabetes Research

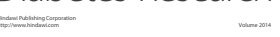

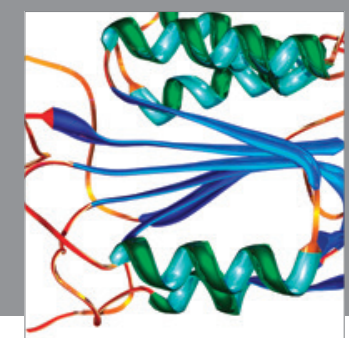

Disease Markers
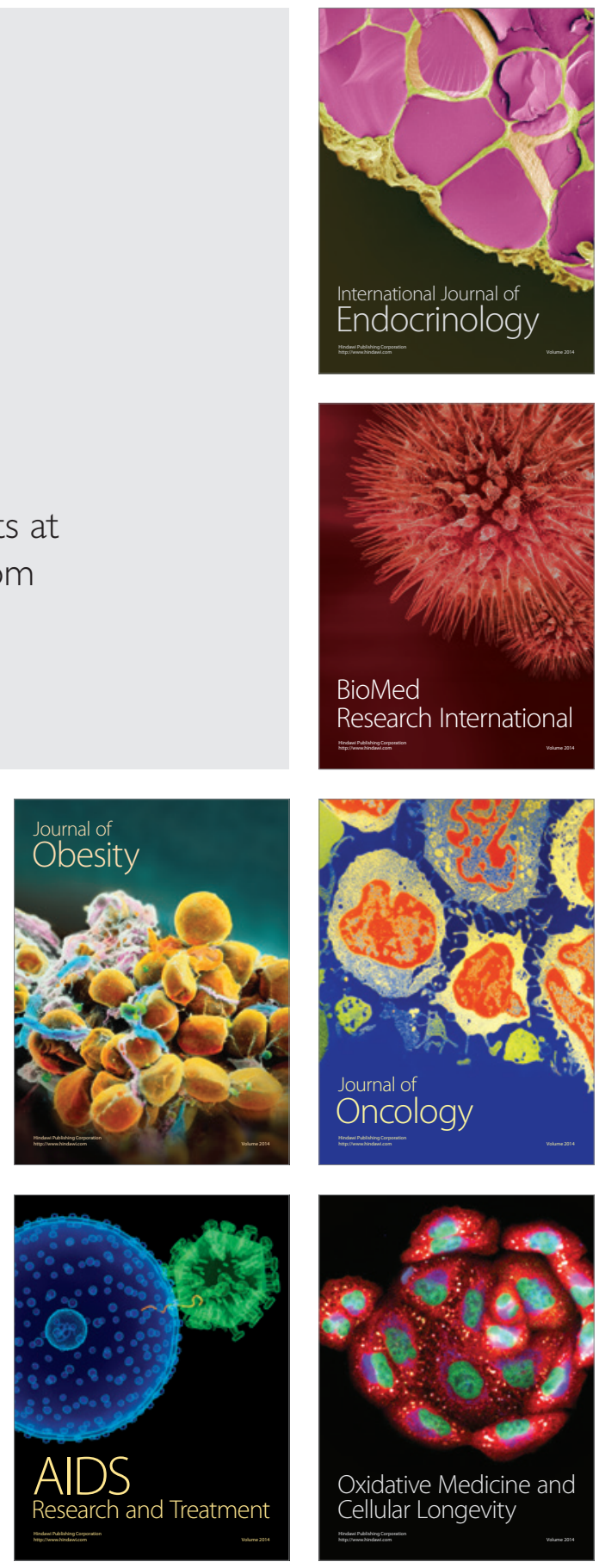